Acta Biologica Plantarum Agriensis 5(1): 46 (2017) ISSN 2061-6716 (Print), 2063-6725 (Online) http://abpa.ektf.hu/
DOI:10.21406/abpa.2017.5.1.46

$4^{\text {th }}$ CC 2017 Abstract

Poster

\title{
INTERESTING DIATOMS FROM A SPECIAL HABITAT
}

Egy különleges élőhely különleges kovaalgái

\author{
Éva ÁcS ${ }^{1}$, Keve T. KISS ${ }^{1}$, Péter DoBosY ${ }^{1}$, Mónika DuLEBA ${ }^{1}$, Luc ECTOR ${ }^{2}$, István \\ GRIGORSZKY ${ }^{1,3}$, Zsuzsa TRABERT ${ }^{1}$, Csaba F. VAD ${ }^{4}$, Carlos E. WeTZEL ${ }^{2}$ \\ \& Angéle FöLDI ${ }^{5}$
}

\begin{abstract}
${ }^{1}$ MTA Centre for Ecological Research, Danube Research Institute, 1113 Budapest, Karolina út 29, Hungary; ${ }^{2}$ Environmental Research and Innovation Department (ERIN), Luxembourg Institute of Science and Technology (LIST), 41 rue du Brill, L-4422 Belvaux, Luxembourg; 3University of Debrecen, Department of Hydrobiology, H-4032 Debrecen, Egyetem tér 1, Hungary; ${ }^{4}$ WasserCluster Lunz, Dr. Carl Kupelwieser Promenade 5, AT-3293, Lunz am See, Austria; ${ }^{5}$ MTA Centre for Ecological Research, GINOP Sustainable Ecosystems Group, 8237

Tihany, Klebelsberg K. u. 3, Hungary; e-mail: acs.eva@okologia.mta.hu
\end{abstract}

The epiphytic diatoms of the soda ponds of bomb craters were sampled in 2014 . The small ponds (area: 7.1-86.5 $\mathrm{m}^{2}$, depth: 4 to $60 \mathrm{~cm}$ ) are located in the northern part of the Kiskunság National Park ( $47^{\circ} 7.403$ 'N, $\left.19^{\circ} 8.187^{\prime} \mathrm{E}\right)$, near the village of Apaj in Hungary. Their salinity ranges from fresh water to moderately saline levels (conductivity of 1.3 to $7.1 \mathrm{mS} \mathrm{cm}^{-1}$ ). This area has patchy surface salinization, because the flow pattern of groundwater results extensive surface salinization in those discharge areas where the infiltrating freshwater does not superimpose the upwelling saline water. The salts origin from the overpressured $\mathrm{NaCl}$-type water of the Pre-Neogene basement and the $\mathrm{NaHCO}_{3}$-type water of the Neogene sediments. The ponds can be characterized by different areal extent, depth and salinity, various conductivity, hydroperiod (1-9 months, the deepest ones do not dry out in years with high amount of precipitation due to probably more or less continuous supply by groundwater), plant coverage and width of macrophyte belt. All of the ponds were sampled except for the ones with very short (shorter than one month) hydroperiod.

A total of 80 diatom taxa, representing 33 genera, were identified in these ponds. The genus Nitzschia was represented by the largest number of species (16), followed by the genus Gomphonema with 9 taxa. IndVal analysis identified 15 species with significant indicator values for ponds. Some interesting, rare or new diatoms for Hungarian flora have also been recorded, including Gomphonema jadwigiae, Halamphora dominici, Navicula wiesneri, Nitzschia austriaca, N. vitrea, Surirella peisonis. 